\title{
Analisis Pengembangan Kognitif dan Emosional Anak Kelompok Bermain Berbasis Kawasan Pesisir Pantai
}

\author{
Yaswinda $^{1 凶}$, Yulsyofriend $^{2}$, Heni Melia Sari ${ }^{3}$ \\ Pendidikan Guru Pendidikan Anak Usia Dini, Universitas Negeri Padang \\ DOI: $\underline{10.31004 / \text { obsesi.v5i2.711 }}$
}

\begin{abstract}
Abstrak
Penelitian ini bertujuan untuk menganalisis keberhasilan program pengembangan kognitif dan emosional anak Kelompok Bermain (KB) Holistik Integratif melalui sistem pembelajaran sentra berbasis kawasan pesisir pantai. Penelitian dilaksanakan di KB yang berada di kawasan Pesisr Pantai dengan melibatkan enam belas anak dan seorang guru, tiga orang kader posyandu serta lima orangtua anak pada pendidikan KB Pasia Mutiara, Ulak Karang Selatan, Kota Padang, Indonesia. Metode Penelitian ini adalah kualitatif dengan pendekatan grounded research. Hasil analisis diperoleh pengembangan kognitif yang dilaksanakan berupa kegiatan dengan model sentra yang dimodisfikasi dengan kondisi. Keunikan program pengembangan terlihat dengan adanya pembelaajaran berbasis pesisir pantai yang terintegrasi dengan posyandu balita. Pembelajatan sentra yang dilakukan cukup unik yang dinamakan Sentra "Buka Lapak" yaitu model sentra dengan hanya menggunakan satu kelas dengan banyak container sentra. Keberhasilan Program Pengembangan terlihat dari terjadinya peningkatan perkembangan yang positf pada aspek kognitif dan emosional anak kelompok Bermain holistik integrative ini.
\end{abstract}

Kata Kunci: kognitif; emosional; kelompok bermain holistik integratif.

\begin{abstract}
This study aims to analyze of the cognitive and holistic development program of children in the integrative Holistic Play group through the coastal area-based center learning model. The research was conducted in a play group located in the Pesisr Pantai area, involving sixteen children in play groups and a teacher, three posyandu cadres and five parents of children in the play group education at Pasia Mutiara, Ulak Karang Selatan, Padang City, Indonesia. This research method is qualitative with a grounded research approach. The results of the analysis show that cognitive development is carried out in the form of activities with a center model that is modified with the conditions. The uniqueness of the development program is evident in the coastal-based learning that is integrated with the toddler posyandu. The learning center that is carried out is quite unique, which is called the "Buka Lapak" Center, which is a center model using only one class with many containers. The success of the Development Program can be seen from the increase in positive development in the cognitive and emotional aspects of the children in this integrative holistic play group.
\end{abstract}

Keywords: cognitive; emotional ; the integrative holistic play group

Copyright (c) 2020 Yaswinda, Yulsyofriend, Heni Melia Sari

$\triangle$ Corresponding author:

Email Address : Yaswinda@fip.unp.ac.id (Padang, Sumatera Barat, Indonesia )

Received 12 August 2020, Accepted 13 September 2020, Published 19 September 2020 


\section{PENDAHULUAN}

Pendidikan Anak Usia Dini diartikan sebagai upaya pendidikan yang diberikan kepada anak mulai usia nol sampai usia delapan tahun. Dasar bagi pembentukan kepribadian manusia secara utuh diberikan kepada anak pada pendidikan ini, ditandai dengan budi pekerti luhur, karakter, terampil dan pandai. Landasan pendidikan anak usia dini terdapat pada kebutuhan anak, yang disesuaikan dengan nilai-nilai yang terdapat dilingkungan sekitarnya dan dilaksanakan sesuai dengan perkembangan anak usia dini (Yaswinda et al., 2018). Menurut (Ulfah, 2019) Holistik integratif merupakan pendekatan yang memerlukan kesinambungan dan keselarasan layanan bagi anak usia dini. Kerjasama antar berbagai pihak sangat diperlukan untuk keberhasilan pendekatan holistik integratif dalam lembaga Pendidikan Anak Usia Dini. Menurut Peraturan Presiden RI Nomor 60 Tahun 2013 Tentang Holistik Integratif) tentang pemenuhan kebutuhan pendidikan anak usia dini. Holistik Integratif adalah pemenihan hak tumbuh kembang anakusia dini sebagai upaa peningkatan kesehatan, gizi, perawatan, pengasuhan, perlindungan, kesejahteraan dan rangsangan pendidikan yang dilakukan secara simultan, sistematis, menyeluruh, terintegrasi dan menyeluruh(Indonesia, n.d.).

PAUD Holistik Integratif (HI) adalah upaya pengembangan anak usia dini yang dilakukan untuk memenuhi kebutuhan esensial anak yang beragam dan saling terkait secara simultan, sistematis dan terintegrasi. Masyarakat berkontribusi dalam pelaksanaan program pengembangan anak Holistik Integratif, baik secara individu, kelompok ataupun organisasi (Ahmad Mushlih, 2018). Menurut (Lina et al., 2019) pengembangan PAUD secara Holistik Integratif memang sangat penting dan harus menjadi tanggung jawab bersama, karena itu keterlibatan semua pihak perlu di bangkitkan. Kurikulum Holistik Inetgratif merupakan kurikulum yang mengintegrasikan segala aspek yang terdapat dalam pengembangan dasar anak secara menyeluruh antara jiwa dan badan serta aspek spiritual dan material untuk memenuhi kebutuhan essensial anak termasuk kesehatan dan gizi, pola pengasuhan dan perlindungan anak (Elyana, 2017). Perkembangan kognitif usia dini menurut Piaget dalam (Suryana, 2018) terjadi sejak usia nol tahun sampai pada tingkat kematangan, proses berpikir secara radikal. Menurut (Eggen \& Kauchak, 2012) pembelajaran kognitif merupakan suatu pembelajaran yang berfokus pada pemikiran anak, yang bisa ataupun tidak bisa mengubah perilaku anak dalam seketika.

Berdasarkan uraian di atas dapat di simpulkan bahwa pendidikan anak usia dini merupakan dasar pembentukan kepribadian manusia secara utuh, oleh sebab itu pembelajaran yang diberikan kepada anak usia dini harus berlandaskan pada kebutuhan anak, dengan pemberian stimulasi pembelajaran yang sesuai dengan kebutuhan anak, maka anak akan lebih siap untuk menghadapi jenjang pendidikan yang lebih tinggi lagi kedepannya.

Brunner dalam (Hijriati, 2016) perkembangan perilaku kognitif terbagi ke dalam tiga periode yaitu: tingkat enaktif, suatu individu berusaha untuk memahami lingkungannya, yang kedua adalah tahap ikonik, masa anak telah menginjakkan kakinya di sekolah dan yang ketiga adalah tahap simbolik/ penggunaan lambang, masa ini anak sudah memasuki tahap SD dan SMP dimana anak sudah mampu untuk berpikir abstrak dan menggunakan bahasa. Pendidikan pada abad 21 memunculkan isu-isu yang diantaranya: (1) latar belakang sosial budaya dan global sepanjang waktu serta menjadi pijakan perkembangan anak; (2) anak sebagai pembuat makna dan pembelajar aktif; (3) budaya keluarga, kelompok, masyarakat menjadi konteks dalam pembelajaran; (4) mewakili dunia; (5) peran pemahaman, identitas, ras, dan jenis kelamin; (6) untuk memahami ilmu pengetahuan dan teknologi; (7) implikasi dari neuroscience (Smidt, 2013).

Pendapat lain dikemukan oleh (Sujiono, 2012), anak usia dini adalah sosok individu yang sedang menjalani suatu proses perkembangan dengan pesat dan fundamental bagi kehidupan selanjutnya. Salah satu aspek yang berkembang tersebut adalah aspek kemampuan kognitif. Kemampuan kognitif anak dapat dapat dilihat dari kegiatan hal yang 
mereka lakuka. Kegiatan tersebut didorong rasa ingin tahu yang besar dari diri anak. Permainan yang didasarkan oleh perasaan suka terhadap benda tersebut dari anak anak membantu kognitif anak cepat berkembang. Perkembangan kognitif sangat diperlukan untuk pengembangan kemampuan kognitif, misalnya mengenal bilangan, mengelompokkan, mengenal bentuk, mengenal ukuran, mengenal geometri, mengenal konsep ruang, mengenal mengenal berbagai pola, konsep waktu, dan lain-lain yang bisa diterapkan dalam kehidupannya sehari hari (Jawati, 2013).

Pengoptimalan kemampuan rasional yang dimiliki oleh suatu individu merupakan salah satu upaya atau proses dari kognitif. Menurut (Dewi et al., 2014) Perkembangan kognitif mempunyai andil yang sangat penting bagi keberhasilan anak dalam belajar, karena sebagian besar aktifitasnya dalam belajar selalu berhubungan dengan berpikir dan mengingat. Hal ini dapat dipandang sebagai suatu perubahan dari suatu keadaan seimbang kedalam keseimbangan baru. Menurut Sukremi et al. (2013) perkembangan kognitif adalah kemampuan untuk mengingat yang dimiliki anak untuk berpikir secara kritis tentang apa yang ada disekitar lingkungannya. Aspek kognisi dimaknai sebagai daya nalar, pengetahuan yang luas, daya ingat serta daya cipta. Anak usia dini perlu mengetahui tentang konsep seperti mengenal warna, ukuran, bentuk, besaran dan arah (Ade Holis, 2016). Berdasarkan uraian di atas dapat di simpulkan bahwa pengembangan kognitif bertujuan untuk mengembangkan kemampuan berpikir anak untuk dapat mengolah perolehan belajarnya, serta dapat menemukan bermacam-macam alternatif pemecahan masalah.

Perkembangan emosional merupakan perkembangan dimana seseorang belajar berinteraksi dengan lingkungan sekitarnya dengan lingkungan sekitarnya dan belajar bagaimana mengekspresikan dan menyampaikan emosinya. Setiap orang mempunyai emosi, rasa senang, marah, kesal dalam menghidupi lingkungannya sehari-hari. Sejalan dengan Ndari et al. (2019) kata emosi berasal dari bahasa laitin, yaitu emovere, yang berarti bergerak menjauh. Arti kata ini menyiratkan bahwa kecenderungan bertindak merupakan hal mutlak dalam emosi. Sejalan dengan itu Susanto (2017) mengatakan bahwa perkembangan emosional berhubungan dengan seluruh aspek perkembangan anak. Setiap orang akan mempunyai emosi rasa senang, marah, kesal dalam menghadapi lingkungannya sehari-hari. Pada tahap ini emosi anak usia dini lebih terperinci, bernuansa atau disebut terdiferensi.

Menurut Suryana (2018) Emosi adalah suatu keadaan yang komplex, dapat berupa getaran jiwa maupun perasaan yang terjadi karena perubahan biologis yang muncul disertai dengan terjadinya suatu perilaku. Fungsi dan peranan emosi pada lingkungan anak: a. Sebagai bentuk tingkah laku yang dapat diterima lingkungannya, sebagai pembentuk kebiasaan dan sebagai upaya pengembangan diri, b. Sebagai bentuk kepribadian dan penilaian tehadap dirinya Sebagai bentuk komunikasi dengan lingkungannya. Berdasarkan uraian di atas dapat diambil kesimpulan bahwa emosi adalah perasaan batin seseorang seperti senang, sedih, kesal, marah, menagis, kasih sayang dan rasa ingin tahu.

PAUD Pasia Mutiara merupakan PAUD dengan layanan kelompok bermain yang terntergrasi dengan poyandu Balita Cinta Sehat. PAUD ini baru didiriakn langsung memprolamirkan diri sebagai PAUD Holistik intergratif dengan menggunakan pendekatan pembelajaran sentra. Walaupun mereka mempunyai satu ruang belajar yang tidak terlalu luas, namun keberanian pengelola untuk menggunakan model sentra menjadi daya tarik sendiri untuk diteliti. Apalagi PAUD ini berada di kawasan pesisir, dan pengelola menyatakan PAUD ini dikelola dengan berwawasan kawasan pesisir pantai yang menjelaskan adanya peningkatan kognitif dan emosional peserta didik. Dari beberapa uraian di atas maka peneliti tertarik untuk melakukan penelitian tentang analisis pengembangan kognitif dan emosional anak KB holistik integratif berbasis kawasan pesisir pantai. 


\section{METODOLOGI}

Penelitian ini menggunakan metode pendekatan deskriptif kualitatif dengan pendekatan grounded research. Pengumpulan data dilakukan dengan teknik studi pustaka, observasi, wawancara, dan dokumentasi. Waktu pelaksanaan penelitian ini selama 6 bulan yaitu antara bulan Januari 2020 sampai Juni 2020 dengan melibatkan 16 anak kelompok bermain, dan 3 orang kader posyandu serta 5 orang tua anak pada pendidikan KB Pasia Mutiara, Ulak Karang Selatan, Kota Padang, Indonesia sebagai data pada pengembangan kognitif dan emosional menggunakan sistem pembelajaran sentra dengan berbasis kawasan pesisir pantai. Menurut Syaodih Sukmadinata (2007), pemilihan lokasi berkenaan dengan penentuan unit, bagian, kelompok, dan tempat dimana orang-orang terlibat di dalam kegiatan atau peristiwa yang akan diteliti. Lokasi penelitian dikawasan pesisir pantai. Alasan penelitian dilakukan diwilayah tersebut karena sebelumnya belum ada PAUD dengan layanan holistic integrative di wilayah tersebut.

Teknik pengumpulan data dengan melakukan observasi, wawancara mendalam dan analisis dokumen serta studi pustaka. Teknik keabsahan data digunakan pada penelitian ini dengan teknik triangulasi. Teknik triangulasi berupa triangulasi sumber data, dimana teknik ini mengarahkan penelitian di dalam mengumpulkan data dengan menggunakan beragam data yang ditemukan. Analisis data dilakukan menggunakan analisis Miles and Hubermen. Menurut Miles \& Huberman (1992) tiga alur kegiatan pada analisis terjadi secara bersamaan yakni: penyajian data, reduksi data dan verifikasi/penarikan kesimpulan. Berikut adalah gambaran bagan penelitian kualitatif yang dilakukan peneliti untuk melakukan penelitian.

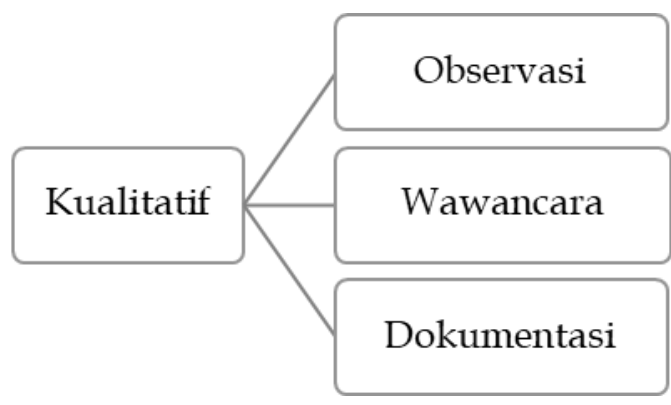

Bagan. Penelitian kualitatif dari (Sugiyono, 2011)

\section{HASIL DAN PEMBAHASAN}

Penelitian ini dilakukan di PAUD Pasia Mutiara Yang berlokasi di Ulak Karang, Kota Padang. Penelitian ini dilakukan selama enam bulan yaitu dari bulan Januari sampai bulan Juni 2020. Pada bulan januari sampai pertengahan bulan maret, pelaksanaan pembelajaran holistik intrgratif berjalan dengan lancar dan tatap muka, namun pada pertengahan bulan maret terjadi pandemi COVID-19 yang mengharuskan anak untuk belajar di rumah dan kegiatan posyandu balita belum dilaksanakan kembali. Sampel penelitian ini adalah anak di PAUD Pasia Mutiara yang berjumlah 16 anak yang terdiri dari 8 anak laki-laki dan 8 anak perempuan.

Berdasarkan hasil wawancara dengan guru, observasi, dan analisis dokumen PAUD Pasia Mutiara diperoleh hasil sebagai berikut. Program holistik integratif yang dilakukan di PAUD Pasia Mutiara berupa: (1) Pendidikan; (2) Kesehatan; (3) Kesejahteraan; (4) Keamanan dan Kenyamanan; dan (5) Parenting.

\section{Pendidikan.}

Program holistik integratif ini menyediakan saran pembelajaran yang dilaksanakan tiga hari dalam seminggu yaitu hari senin, rabu dan kamis dengan menggunakan sistem pembelajaran sentra, sentra yang digunakan yaitu sentra persiapan, sentra main peran, sentra kreativitas, sentra imtaq, sentra olah tubuh dan sentra balok. Sentra olah tubuh dilksanakan 
di Lapangan PAUD. Sistem pembelajaran yang digunakan dinamakan sentra "Buka Lapak" yaitu alat pembelajaran per setiap sentra di masukkan dalam satu kotak besar sehingga ketika pembelajaran sentra dilaksanakan guru mengeluarkan kotak yang berisi alat pembelajaran sentra tersebut dan nantinya setelah selesai dilaksanakan dimasukkan kembali ke dalam kotak besar tersebut.

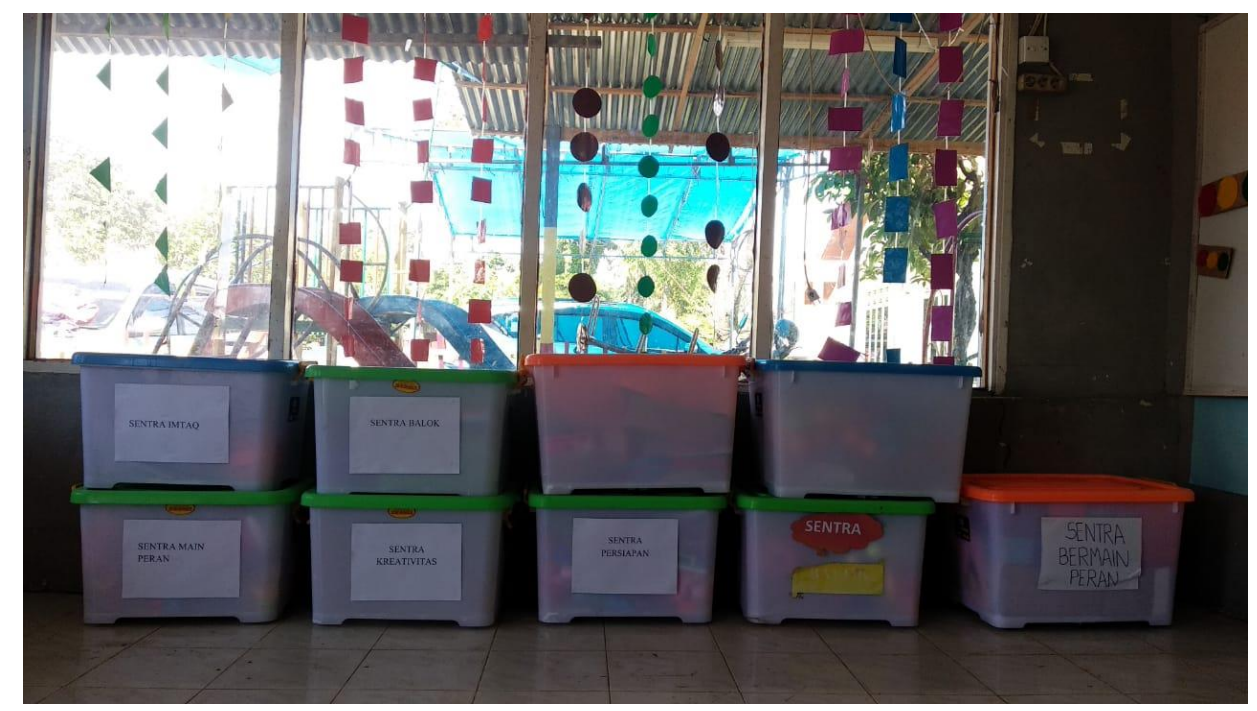

Gambar 1. Kontainer Penyimpanan Media Pembelajaran Berdasarkan Sentra Bulan Juni.

Berikut adalah tema yang digunakan pada semester 1 yaitu bulan Januari sampai

Tabel 1. Tema Pembelajaran

\begin{tabular}{lll}
\hline NO & TEMA & ALOKASI WAKTU \\
\hline $\mathbf{1 .}$ & Pekerjaan & 3 minggu \\
\hline 2. & Air, Udara dan Api & 3 minggu \\
\hline 3. & Alat Komunikasi & 3 minggu \\
\hline 4. & Tanah Air ku & 3 minggu \\
\hline $\mathbf{5 .}$ & Alam Semesta & 3 minggu \\
\hline & Jumlah & 15 minggu \\
\hline
\end{tabular}

Berdasarkan hasil observasi yang didokumentasikan pada tabel 2 bagian a, pada saat kelas membuka Sentra seni dan Kreativitas, anak membuat karya seni didampingi guru dan Kader PAUD. Anak-anak terlihat sangat gembira di saat sentra seni dibuka. Karya anak di saat kegiatan seni ini kemudian di tempelkan di papan display yang tersedia. Berdasarkan hasil wawancara dan observasi, terlihat bahwa Kegiatan ibadah dilaksankan 2 klai dalam sebulan. Kegiatan saat sentra Ibadah antra lain adalah sholat berjamah dan pengenalan doodoa sehari-hari. Berdasarkan wawancara dengan orang tua terungkap bahwa keberadaan sentra ibadah ini membawa pengaruh positif kepada anak mereka, karena anak-anak mereka sudah hafal beberapa doa harian seperti doa mau makan dan doa mau tidur dengan mengikuti kegiatan pembelajaran di kelompok bermain. Kegiatan di sentra IMTAQ didokumentasikan di table 2, bagian b. .

Tabel 2. Dokumentasi Kegiatan Anak Saat Pembelajaran Model Sentra “Buka Lapak” 


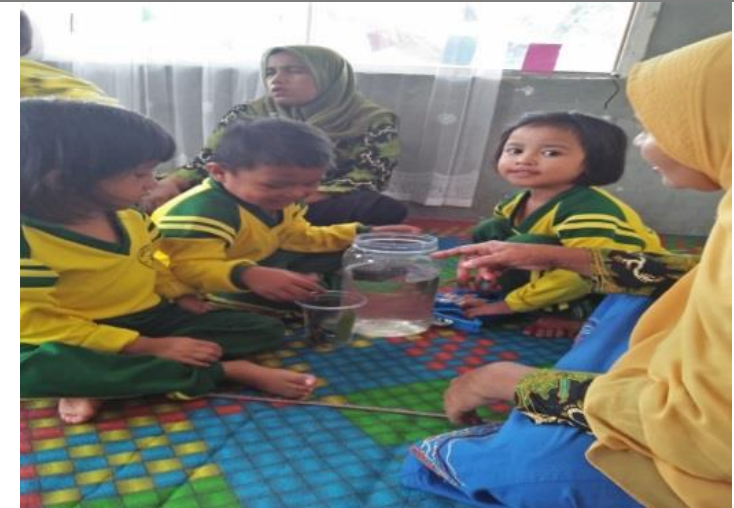

a. Anak belajar saat sentra seni dan kreativitas kepada anak

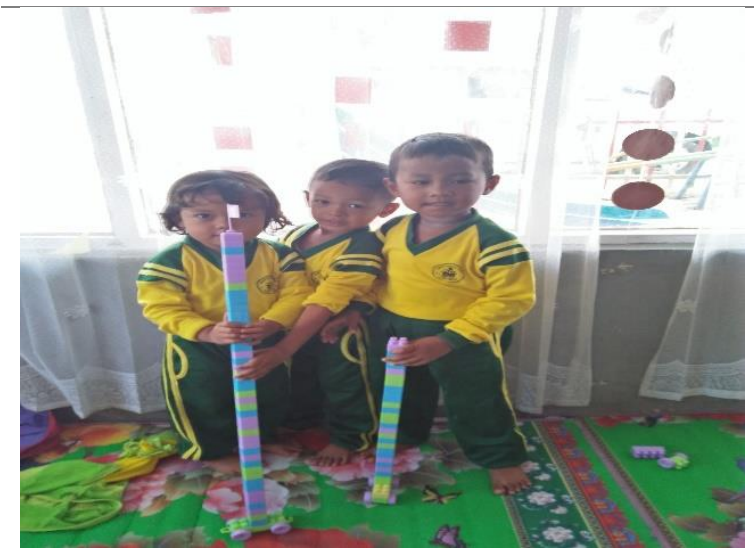

c. Anak menunjukkan hasil dari menyusun balok saat Sentra Balok

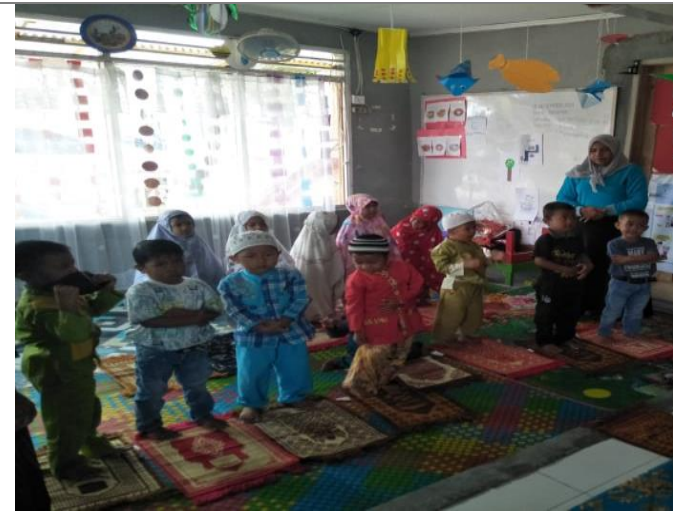

b. Anak belajar sholat berjamaah saat Sentra IMTAQ

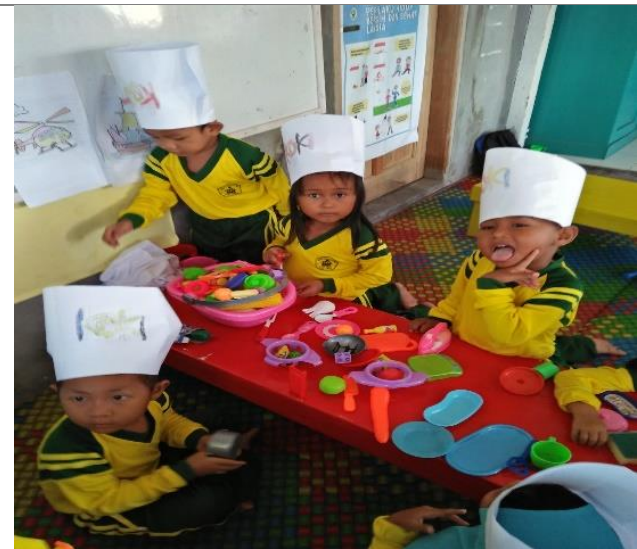

d. Kegiatan saat Sentra main peran menjadi koki

Salah satu bentuk pengembangan social emosional di PAUD ini adalah dengan membiasakan anak mengkomunikasikan hasil kerja mereka, seperti karya bangunan tinggi dari balok yang disusun di gambar 5 di atas. Anak-anak kemudian menceritakan karya mereka dihadapan teman dan guru dengan bahasa sederhana dan ditanya oleh guru, apa yang mereka buat saat sentra Balok dibuka, dokumentasikan di tabel 2 bagian c. Pada saat sentra main peran dibuka, anak-anak tampak senang dan bermain dengan gaya mereka masing-masing. Kegiatan ini dilaksanakan untuk menstimulasi kognitif dan emosional anak serta kreativitas anak. Pada table 2 bagian d di atas anak-anak bermain peran sebagai Penjual dan pembeli di Pasar.

Pada pertengahan bulan maret 2020 telah terjadi pandemi COVID-19, sehingga pembelajaran dilaksanakan secara daring kepada anak-anak, karena pada saat itu juga sedang penerapan PSSB yang yang tidak memperbolehkan masyarakat untuk berkumpul-kumpul di keramaian. Guru menerangkan tema-tema pembelajaran dengan mengirim video ke dalam group Whatsapp orang tua, ketika salah satu orang tua tidak mengerti, bisa langsung ditanyakan melalui group tersebut, sehingga pembelajaran tetap berlangsung dengan lancar.

\section{Kesehatan.}

Program kesehatan yang dilakukan yaitu posyandu balita, posyandu balita yang dilaksanakan di PAUD Pasia Mutiara di lakukan setiap satu bulan sekali, pada hari rabu minggu kedua, kegiatan posyandu balita ini bekerja sama dengan Puskesmas Ulak Karang dan kader Posyandu RW01 Kelurahan Ulak Karang Selatan. Pemeriksaan yang dilakukan seperti pemeriksaan tinggi dan berat badan, pemeriksaan tahap perkembangan anak, imunisasi, pemberian vitamin, serta makanan bergizi kepada anak. 


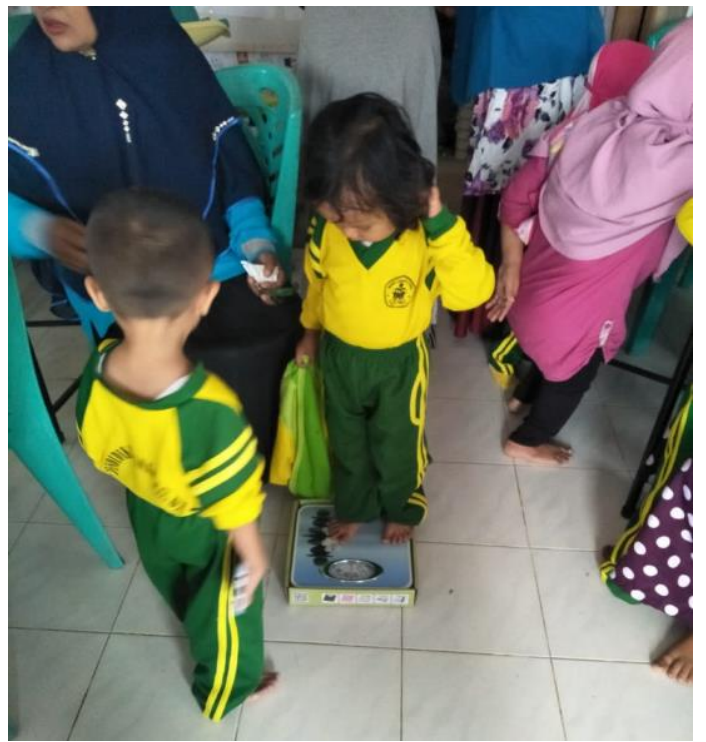

\section{Gambar 2. Kegiatan PAUD yang terintegrasi Posyandu Balita}

\section{Kesejahteraan.}

Kesejahteraan anak pada program holistik integratif di PAUD Pasia Mutiara yaitu dengan pemberian baju gratis, tas gratis, alat tulis yang diberikan juga gratis. Anak-anak juga mendapatkan makanan tambahan gratis setiap kali hari pembelajaran dan kegiatan Posyandu berlangsung berupa susu kotak dan makanan snack berbasis ikan seperti bakso ikan, nugget ikan dan dimsum.

\section{Keamanan dan Kenyamanan.}

PAUD Pasia Mutiara berusaha memenuhi standar sarana prasarana, salah satunya adalah adanya pagar sebagai pengaman karena lokasi sekolah berada dekat dengan jalan. Selain itu PAUD Pasia sudah dilegkapi dengan toilet yang bersebelahan dengan ruang belajar, jadi tidak jauh dari ruang belajar anak

\section{Parenting.}

Kegiatan parenting di PAUD Pasia Mutiara Belum berjalan dengan baik, itu di karenakan pada saat penelitian dilakukan, sedang terjadinya wabah COVID-19, namun kegiatan pembelajran tetap dapat dilaksanakan yaitu dengan menggunakan aplikasi WHATSAPP sebagai media komunikasi antara Guru dan Orang tua, sehingga pelaksaan program holistik integratif ini tetap berjalan dengan baik. Bersadarkan wawancara dengan kader, sebelum penelitian dilakukan, pada awal tahun ajaran 2019/2020 sudah terbentuk paguyuban orang tua, salah satu program yang terlaksana pada bulan Novemver 2019 adalah kegiatan rekreasi bersama orang tua, anak dan guru serta kader Posyandu. Kegiatan lain yang dilaksanakan dengan melibatkan orang tua adalah pada saat peresmian Kelompok Bermain PAUD Mutiara, dimana anak-anak belajar gerak lagu dengan bimbingan kader dan orang tua serta guru. Kegiatan seni keudian ditampilkan di depan Bunda PAUD Kota Padang.

Berikut adalah dokumentasi kegiatan yang dilakukan anak untuk mengembangkan aspek perkembangan anak, termasuk perkembangan kognitif dan perkembangan emosional anak. 


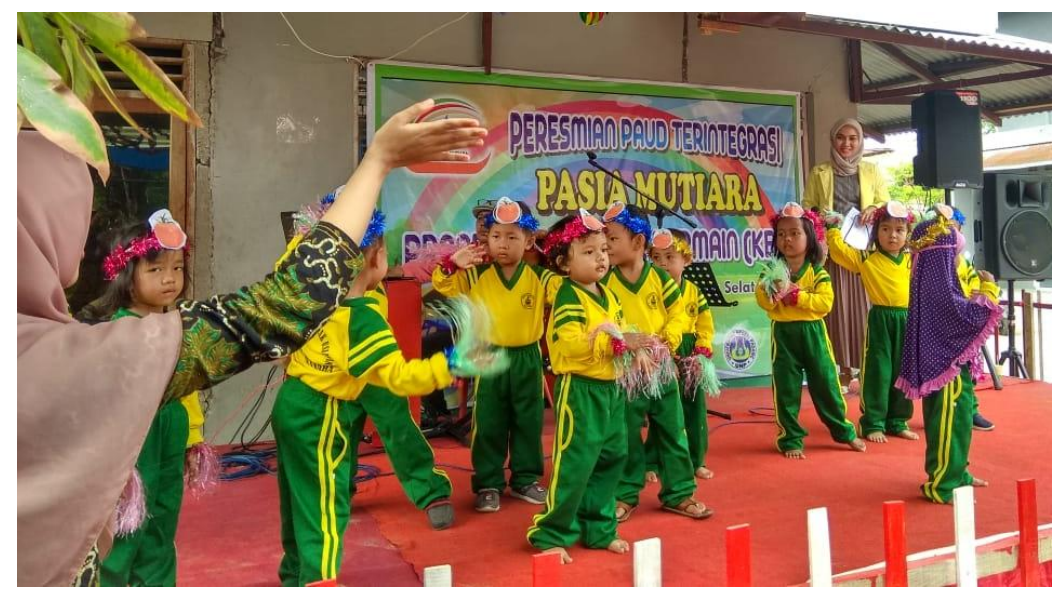

Gambar 3. Dokumentasi saat Anak-anak Kelompok Bermain Tampil Gerak dan Lagu

\section{Perkembangan Kognitif dan Sosial Anak}

Prinsip pembelajaran holistik dilaksanakan dengan mengembangkan semua aspek perkembangan anak, dimana aspek tersebut saling mempengaruhi dan tidak bisa dipisahkan satu sama lain. Sedangkan prinsip pembelajaran integratif dilaksanakan dengan cara menggabungkan atau menyatukan. Oleh karena itu pelaksanaan pembelajaran holistik integratif dilaksanakan dengan mengembangkan semua perkembangan anak aspek melalui cara menyatukan atau menggabungkan semua aspek perkembangan tanpa memisahkan antara aspek yang satu dengan aspek yang lainnya (Pramudyani et al., 2017).

Pengembangan kognitif dan emosional di PAUD Pasia Mutiara Ulak Karang dilakukan dengan sistem pembelajaran sentra. Sentra yang terdapat di PAUD tersebut seperti sentra seni, sentra persiapan, sentra imtaq, kreativitas, sentra main peran dan sentra balok. PAUD ini menggunakan konsep belajar sambil bermain. Peranan guru di sekolah sangat menentukan dengan model pembelajaran yang tepat guru lebih mudah untuk meningkatkan aspek perkembangan yakni aspek kognitif dan aspek emosional. Berdasarkan hasil observasi dan pengamatan yang dilakukan di PAUD Pasia Mutiara Ulak Karang, menemukan bahwa perkembangan kognitif dan emosional anak berkembang dengan baik setelah dilaksanakan pembelajaran yang diberikan kepada anak dan yang diketahui bahwa perkembangan kognitif dan emosional anak KB masih perlu di bimbing. Untuk menentukan perkembangan anak, di butuhkan pedoman sebagai penentu untuk menyimpulkan perkembangan anak, berikut adalah tabel perkembangan anak PAUD:

Tabel 3. Kategorisasi Perkembangan Anak

\begin{tabular}{lcl}
\hline \multicolumn{1}{c}{ Kategori } & & \multicolumn{1}{c}{ Penjelasan } \\
\hline $\begin{array}{l}\text { a. } \text { Berkembang } \\
\text { Sangat Baik }\end{array}$ & BSB & $\begin{array}{l}\text { Dikatakan BSB apabila anak dapat menyelesaikan tugas tanpa } \\
\text { bantuan Guru, dan dapat membantu teman yang kesulitan } \\
\text { menyelesaikan tugas tersebut. }\end{array}$ \\
\hline $\begin{array}{l}\text { b. } \text { Berkembang } \\
\text { Sesuai } \\
\text { Harapan }\end{array}$ & BSH & $\begin{array}{l}\text { Dikatakan BSH apabila anak dapat menyelesaikan tugas secara } \\
\text { mandiri tanpa harus diingatkan atau diberikan contoh oleh Guru. }\end{array}$ \\
\hline $\begin{array}{l}\text { c. } \begin{array}{l}\text { Mulai } \\
\text { Berkembang }\end{array} \\
\text { d. Belum } \\
\text { Berkembang }\end{array}$ & BB & $\begin{array}{l}\text { Dikatakan MB apabila masih harus diingatkan dan atau di bantu } \\
\text { oleh Guru }\end{array}$ \\
\hline
\end{tabular}

Berdasarkan hasil wawancara dan analisis dokumen diperoleh data bahwa program pembelajaran holistic integrative dengan model sentra yang dilaksanakan telah dapat meningkatkan kognitif dan sosial emosional anak kelompok bermain di PAUD tersebut. 
Berikut tabel 4, pencapaian perkembangan anak dari sebelum dilaksanakan dan setelah dilaksanakannya kegiatan analisis pengembangan kognitif dan emosional anak di Kelompok Bermain holistik integratif berbasis kawasan pesisir pantai.

Tabel 4. Hasil Analisis Perkembangan Kognitif Anak

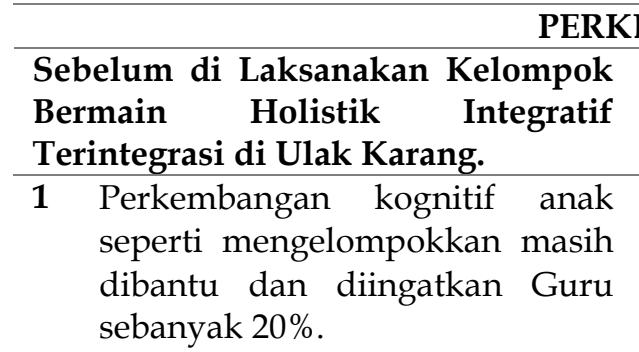

2 Mengenal warna masih dibantu dan diingatkan Guru sebesar $25 \%$.

3 Mengenal bilangan, berhitung, mengenal geometri masih dibantu dan diingatkan Guru sebesar $35 \%$.

$4 \quad$ Mengenal ukuran masih dibantu dan diingatkan Guru sebesar.

Setelah dilaksanakan pembelajaran holistik integratif, dalam mengembangkan kognitif anak seperti mengelompokkan masih dibantu dan diingatkan Guru yang sebelumnya sebanyak $20 \%$ kini berkurang menjadi $10 \%$. Anak dapat belajar mengelompokkan seperti pisang, semangka, adalah jenis buah-buahan, kupu-kupu, capung, burung adalah jenis binatang bersayap, mobil, motor dan bus adalah termasuk kendaraan darat, helikopter, pesawat adalah kendaraan di udara secara mandiri tanpa harus diingatkan oleh Guru.

Perkembangan kognitif anak berkembang dengan baik seperti anak sudah dapat mengenal warna dasar seperti merah, kuning, dan biru secara mandiri tanpa harus diingatkan oleh Guru.

Dapat menghitung angka 1-10yang dilakukan sambil bernyanyi dan mengenal bentuk segitiga, segiempat dan lingkaran secara mandiri tanpa harus diingatkan oleh Guru.

Dapat mengenal ukuran melalui pembelajaran mengurutkan dari buah kecil, sedang dan besar, sapi yang kecil, sedang, dan besar, mengenal konsep ruang seperti kanan, kiri, atas bawah, mengenal bentuk lingkaran, persegi empat, segitiga contohnya adalah rumah secara mandiri tanpa harus diingatkan oleh Guru.

5 Mengenal konsep waktu dan mengenal konsep ruang anak di Kawasan pesisir pantai, belum berkembang dengan baik, karena di lingkungan sekitar mereka tidak ada sekolah masih dibantu dan diingatkan Guru sebesar $37 \%$.

Kemampuan berpikir logis anak dapat dilatih dengan kegiatan menggelompokkan benda sesuai warna, ukuran, jenis dan bentuk. Hal ini dapat terjadi dikarenakan anak melakukan proses pemilihan benda sesuai dengan kualifikasi atau kriteria yang telah ditentukan (Hapsari, 2020). Semua itu dilakukan sesuai dengan usia anak kelompok bermain yakni perkembangan kognitif berkaitan dengan kemampuan berpikir dan cara kegiatan berpikir tersebut bekerja. Anak seharusnya sudah dikenalkan dengan komponen keterampilan kognitif semenjak usia dini. Komponen keterampilan kognitif dikembangkan dengan optimal secara optimal dan menyenangkan di bidang matematika, bahasa dan sains. Anak perlu dibekali keterampilan kognitif semenjak dini untuk diterapkan di kehidupan sehari-hari (Hayati et al., 2017). Perkembangan emosi menurut (Afrih Lia, 2018), merupakan warna kehidupan yang dimiliki oleh seseorang untuk mengungkapkan situasi tertentu untuk menjalin hubungan atau interaksi dengan orang lain. Dalam perkembangan emosional 
anak, anak-anak sekarang dapat menempatkan diri mereka dalam pada saat tugas di berikan, juga saat bermain bersama dengan temannya.

Berdasarkan analisis dokumen Laporan Perkembangan anak, hasil obesrvasi dan wawancara dengan guru diperoleh data pencapaian perkembangan anak dari sebelum dilaksanakan dan setelah dilaksanakan nya kegiatan analisis pengembangan kognitif dan emosional anak di Kelompok Bermain holistik integratif berbasis kawasan pesisir pantai, di tabel 5 sebagai berikut.

Tabel 5. Hasil Analisis Perkembangan Emosianal Anak

\begin{tabular}{|c|c|}
\hline \multicolumn{2}{|c|}{ PERKEMBANGAN EMOSIONAL } \\
\hline $\begin{array}{l}\text { Sebelum di Laksanakan } \\
\text { Kelompok Bermain Holistik } \\
\text { Integratif Terintegrasi di } \\
\text { Ulak Karang }\end{array}$ & $\begin{array}{l}\text { Setelah di Laksanakan Kelompok Bermain Holistik } \\
\text { Integratif Terintegrasi di Ulak Karang. }\end{array}$ \\
\hline $\begin{array}{l}\text { Sebelumnya masih sangat } \\
\text { egois, mudah marah, dan } \\
\text { malu-malu. Sebanyak } \\
30 \%\end{array}$ & $\begin{array}{l}\text { Perkembangan anak pada tahap pelaksanaan pembelajaran } \\
\text { holistik integratif masih egois, mudah marah, dan malu-malu } \\
\text { sebanyak } 5 \% \text {, Namun setelah dilaksanakan pembelajaran } \\
\text { holistik integratif ini Sudah dapat dikendalikan dengan baik } \\
\text { karena adanya pembelajaran yang diberikan kepada mereka } \\
\text { anak menjadi lebih sabar, mau menunggu giliran, bisa } \\
\text { mengendalikan egoisnya sebanyak }\end{array}$ \\
\hline $\begin{array}{l}\text { Sebelumnya ruka } \\
\text { berteriak- teriak ketika } \\
\text { meminta sesuatu kepada } \\
\text { guru, orang tua dan } \\
\text { teman sebanyak } 40 \% .\end{array}$ & $\begin{array}{l}\text { Perkembangan anak pada tahap pelaksanaan pembelajaran } \\
\text { holistik integratif mulai berkurang yaitu menjadi } 15 \% \text {, itu } \\
\text { dikarenakan anak di PAUD Pasia Mutiara tersebut dalam } \\
\text { usia Kelompok bermain, jadi sifat manja, suka berteriak- } \\
\text { teriak masih dilakukan ketika berbicara kepada orang tua. } \\
\text { Namun setelah pembelajaran holistik dilaksakan anak bisa } \\
\text { meminta dengan cara yang baik kemudian mengucapkan } \\
\text { terimakasih }\end{array}$ \\
\hline
\end{tabular}

Keberhasilan aktivitas anak dalam perkembangan emosional ditandai dengan mampunya anak untuk mengelola emosi yang muncul terhadap suatu perilaku. Anak yang masih menunjukkan sikap ego atau menang terhadap orang sekitar, tidak bersedia bermain dengan temannya, tidak mampu bertanggung jawab terhadap sesuatu serta tidak mampu untuk menjalin kerjasama merupakan contoh hambatan dalam perkembangan aspek emosional (Ananda \& Fadhilaturrahmi, 2018). Seiring dengan pertambahan usia perkembangan emosi seseorang mengalami kematangan. Sehingga terjadi perubahan terhadap frekuensi, intensitas serta jangka waktu terjadinya berbagai macam emosi (Hurlock, 2013). Senyum (Martani, 2012) merupakan ekspresi emosi senang, dengan senyum anak akan mampu memberikan tanda kepada sekitarnya tentang situasi yang dialami dan kebutuhan untuk melakukan hubungan antar pribadi. Singkat kata, emosi membantu anak sepanjang waktu untuk bertahan dan berkomunikasi dengan lingkungan. Emosi berkembang sepanjang waktu, emosi pada anak usia dini berkembang dari yang sederhana menjadi suatu kondisi yang kompleks. Emosi berkembang sebagai hasil interaksi dengan lingkungannya. Pemberian stimulus yang kurang tepat kepada anak akan mengakibatkan bumerang bagi pendidik yang mampu memunculkan problematika perkembangan emosi anak berupa rasa takut, cemas dan rendah diri dan pemalu (Nurjannah, 2017).

Perkembangan emosional dan perkembangan kognitif anak ditingkatkan tidak hanya di ruangan kelas, melainkan dapat diterapkan metode lain yang dilakukan dapat dilakukan di luar kelas seperti di perkarangan sekolah yang sesuai dengan prinsip PSB bahwa pembelajaran berpusat pada anak, metode belajar yang bervariasi, belajar sambil bermain akan mengembangkan kognitif, sosial emosional, dan fisik anak (Yaswinda, 2019). 
Berdasarkan analisis dokumen Laporan Perkembangan anak di semester 1 dan semester 2 tahun jaran 2019/2020 maka diperoleh perbandingan analisis perkembangan kognitif dan emosional anak kelompok bermain holistik integratif berbasis pesisir pantai.sebagai berikut.

Tabel 5. Perbandingan Analisis perkembangan Kognitif dan Emosional Anak

\begin{tabular}{|c|c|}
\hline \multicolumn{2}{|c|}{ Juli - Desember $2019 \quad$ Januari -juni 2020} \\
\hline \multicolumn{2}{|r|}{ Kognitif } \\
\hline $\begin{array}{l}\text { Semua anak belum mengenal } \\
\text { warna, belum } r \text { lancar } \\
\text { menghitung 1-10, mengenal } \\
\text { bentuk geometri, mengenal } \\
\text { ukuran, mengenal konsep } \\
\text { ruang, mengenal konsep waktu. }\end{array}$ & $\begin{array}{l}\text { 1. Anak sudah mengenal warna dasar merah, kuning, dan } \\
\text { biru. } \\
\text { 2. Anak lancar menghitung angka 1-10 karena dilakukan } \\
\text { dengan bernyayi agar anak lebih mudah mengingat. } \\
\text { 3. Anak mengenal bentuk lingkaran, segitiga dan segi } \\
\text { empat. } \\
\text { 4. Anak dapat membedakan besar dan kecil. } \\
\text { 5. Anak mengenal kegiatan pagi sebelum berangkat } \\
\text { sekolah mandi, sarapan, Mengenal siang, makan siang, } \\
\text { tidur, kegiatan sore main dan mandi }\end{array}$ \\
\hline \multicolumn{2}{|r|}{ Emosional } \\
\hline $\begin{array}{l}\text { 1. masih sangat egois, mudah } \\
\text { marah, dan malu- malu, } \\
\text { manja. } \\
\text { 2. berebutan mainan }\end{array}$ & $\begin{array}{l}\text { 1. Sudah mau belajar di kelas, tanpa di temani orang tua } \\
\text { (mandiri). } \\
\text { 2. Berbagi mainan dengan temannya. } \\
\text { 3. Sabar menunggu giliran }\end{array}$ \\
\hline $\begin{array}{l}\text { 3. Berbicara keras ketika } \\
\text { meminta bantuan kepada } \\
\text { guru, orang tua }\end{array}$ & $\begin{array}{l}\text { 4. Berbicara baik kepada guru dan teman } \\
\text { 5. Mengucapkan terimakasih setelah meminta bantuan }\end{array}$ \\
\hline
\end{tabular}

Berdasarkan perolehan hasil di atas, dapat kami simpulkan bahwa program pengembangan kognitif dan emosional anak Kelompok Bermain di PAUD Pasia Mutia telah berhasil Karena telah dapat menunjukkan perkembangan kognitif dan emosional anak sesuai tahap perkembnagan. Program pengembangan kognitif dan sosial yang dilaksanakan tergambar dalam diagram berikut ini.

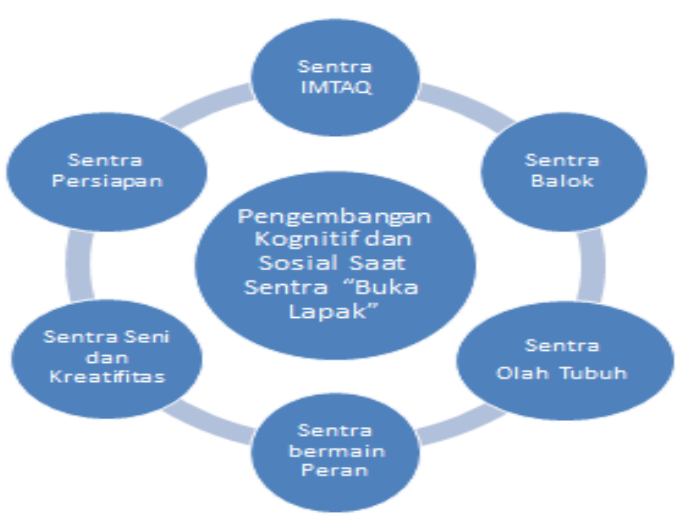

Gambar 4. Diagram Pengembangan Kognitif dan Sosial Saat Sentra "Buka Lapak"

Berdasarkan hasil penelitian maka kami dapat menganalisis kekurangan dan kelebihan Pembelajaran Holistik Integratif di Kelompok Bermain PAUD Pasia Mutiara sebagai berikut. Kekurangan Prgram Pegembangan Pembelajaran holistik integratif yang dilaksanakan di sekolah ini adalah ruang kelas yang kurang luas dan lembaga tersebut berada denkat dengan pinggir jalan sehingga butuh pengawasan agar anak tetap dalam pengasahan agar tidak keluar pagar. Ealin itu, peneliti belum menemukan bentuk yang unik dari program 
terkait PAUD berwawasan pesisir pantai kecuali pada saat makan tambahn yang diberikan berbasis hasil laut. Sedangkan dalam pengembangan tema belum menggambarkan kekhasan berwawasan pesisir. Namun di balik kekuarangan terebut, Kelebihan pengemabangan program ini adalah pelaksanaan pembelajaran tetap bisa dilaksanakan dengan menggunakan sistem sentra, walaupun hanya satu kelas karena PAUD tersebut menggunakan sentra yang dinamakan "Buka Lapak", yaitu alat pembelajaran per setiap sentra di masukkan dalam satu kotak besar sehingga ketika pembelajaran sentra dilaksanakan guru mengeluarkan kotak yang berisi alat pembelajaran sentra tersebut dan nantinya setelah selesai dilaksanakan dimasukkan kembali ke dalam kotak besar tersebut. Kelebihan lain adalah anak k-anak kelompok bermain di PAUD Pasia Nutiara mendapatkan kesejahtraan berupa pembelajaran gratis dan makanan tambahan gratis yang berbasis ikan / hasil laut lainnya.

\section{SIMPULAN}

Keunikan program pengembangan terlihat dengan adanya pembelajaran berbasis pesisir pantai yang terintegrasi dengan posyandu balita. Pembelajaran sentra yang dilakukan cukup unik yang dinamakan Sentra "Buka Lapak" yaitu model sentra dengan hanya menggunakan satu kelas dengan banyak container sentra. Keberhasilan program pengembangan terlihat dari peningkatan perkembangan yang positf pada aspek kognitif dan emosional. Pembelajaran dengan menggunakan sistem sentra yang sesuai dengan usia $\mathrm{KB}$, sangat dirasakan manfaatnya bagi anak dan orang tua. Anak sudah lebih mandiri dan berani meminta maaf jika berbuat salah, sabar menunggu giliran. Kemampuan kognitif anak dapat mengenal mengenal warna, berhitung, mengelompokkan, mengenal bilangan, mengenal bentuk, geometri, mengenal ukuran, mengenal konsep ruang, serta mengenal konsep. Sangat diperlukan pembelajaran yang sesuai dengan usia anak yaitu dengan sistem pembelajaran sentra model buka lapak. Model ini dapat diterapkan pada PAUD yang mempunyai ruang terbatas untuk menrapkan model pembelajaran sentra.

\section{UCAPAN TERIMA KASIH}

Terimakasih kepada DRPM, Kemenristekdikti BRIN yang telah membiayai penelitian ini dan LP2M UNP yang telah memfasilitasi penelitian ini.

\section{DAFTAR PUSTAKA}

Ade Holis. (2016). Belajar Melalui Bermain untuk Pengembangan Kreativitas dan Kognitif Anak Usia Dini. Jurnal Pendidikan Universitas Garut, 10(1), 23-37.

Afrih Lia, N. F. (2018). Moncer; Media untuk Menstimulus Kemampuan Matematic AUD. ThufuLA: Jurnal Inovasi Pendidikan Guru Raudhatul Athfal, 6(1), 99. https://doi.org/10.21043/thufula.v6i1.4636

Ahmad Mushlih, R. M. I. (2018). Analisis Kebijakan PAUD Mengungkap Isu-Isu Menarik Seputar AUD. Jawa Tengah: Mangkubumi. Penerbit Mangku Bumi.

Ananda, R., \& Fadhilaturrahmi, F. (2018). Peningkatan Kemampuan Sosial Emosional Melalui Permainan Kolaboratif pada Anak KB. Jurnal Obsesi: Jurnal Pendidikan Anak Usia Dini, 2(1), 20-26. https:// doi.org/10.31004/obsesi.v2i1.3

Dewi, N. M. O., Wirya, N., Asril, N. M., \& Psi, S. (2014). Penerapan Metode Bermain Berbantuan Media Balok Cruissenare Untuk Meningkatkan Perkembangan Kognitif Pada Anak Usia Dini. Jurnal Pendidikan Anak Usia Dini Undiksha, 2(1). https://doi.org/10.23887/paud.v2i1.2982

Eggen, P., \& Kauchak, D. (2012). Strategi dan model pembelajaran. Jakarta: Indeks.

Elyana, L. (2017). Kurikulum holistik integratif anak usia dini dalam implementasi self regulated learning. Prosiding HIPKIN Jateng, 1(1), 1-7.

Hapsari, R. (2020). Pengembangan Kognitif Anak Melalui Kegiatan Mengelompokkan Benda Dengan Media Bola Warna. Generasi Emas: Jurnal Pendidikan Islam Anak Usia Dini, 3(1), 18-24. https:/ / doi.org/10.25299/jge.2020.vol3(1).5251 
Hayati, N., Cholimah, N., \& Christianti, M. (2017). Identifikasi Keterampilan Kognitif Anak Usia 2-6 tahun di Lembaga PAUD Kecamatan Sleman, Yogyakarta. Jurnal Pendidikan Anak, 6(2), 181-189. https:/ / doi.org/10.21831/jpa.v6i2.17705

Hijriati. (2016). Tahapan perkembangan kognitif pada masa early childhood. Jurnal Pendidikan Anak, 1(2), 1-17.

Hurlock, E. B. (2013). Perkembangan Anak Jilid 1 Edisi Keenam (Terjemahan). Erlangga.

Indonesia, P. R. (n.d.). Peraturan Presiden Nomor 19 Tahun 2013'Tentang Holistik Integratif.

Jawati, R. (2013). Peningkatan Kemampuan Kognitif Anak Melalui Permainan Ludo Geometri Di Paud Habibul Ummi Ii. Spektrum: Jurnal Pendidikan Luar Sekolah (PLS), 1(1), 250. https:// doi.org/10.24036/spektrumpls.v1i1.1537

Lina, L., Suryana, D., \& Nurhafizah, N. (2019). Penerapan Model Evaluasi CIPP dalam Mengevaluasi Program Layanan PAUD Holistik Integratif. Jurnal Obsesi: Jurnal Pendidikan Anak Usia Dini, 3(2), 346. https:/ / doi.org/10.31004/obsesi.v3i2.200

Martani, W. (2012). Metode Dan Stimulasi Perkembangan Anak Usia Dini. Psikologi, 39(1), 1.

Miles, M. B., \& Huberman, A. M. (1992). Analisis data kualitatif jakarta: Universitas Indonesia. UI press.

Ndari, S. S., Chandrawaty, C., Kibitiah, K., \& Wahyudin, E. (2019). Metode Perkembangan Sosial Emosional Anak Usia Dini. Early Childhood: Jurnal Pendidikan, 3(1), 22-35.

Nurjannah, N. (2017). Mengembangkan Kecerdasan Sosial Emosional Anak Usia Dini melalui Keteladanan. Hisbah: Jurnal Bimbingan Konseling Dan Dakwah Islam, 14(1), 50-61. https:// doi.org/10.14421/hisbah.2017.141-05

Pramudyani, A. V. R., Kurniawan, M. R., \& Rasyid, H. (2017). Kurikulum holistik integratif berbasis permainan tradisional pada PAUD di Yogyakarta. Jurnal Penelitian Ilmu Pendidikan, 10(2), 86-96. https://doi.org/10.21831/jpipfip.v10i2.17910

Smidt, S. (2013). The developing child in the 21st century: A global perspective on child development, Second edition. In The Developing Child in the 21st Century: A Global Perspective on Child Development, Second Edition. Routledge. https:/ / doi.org/10.4324/9780203483640

Sugiyono. (2011). Metode Penelitian Kuantitatif, Kualitatif dan RED. Alfabeta.

Sujiono. (2012). Konsep Dasar Pendidikan Anak Usia Dini. In PT Indeks. https:// doi.org/10.1007/978-981-10-4151-8_4

Sukremi, K., Agung, A. A. G., \& Ambara, D. P. (2013). Penerapan Metode Drill Berbantuan Media Tangram untuk Meningkatkan Perkembangan Kognitif Anak Kelompok B2 di TK Pradnya Paramita. Jurnal Pendidikan Anak Usia Dini Undiksha, 1(1). https:// doi.org/10.23887/paud.v1i1.1136

Suryana, D. (2018). Stimulasi \& Aspek Perkembangan Anak. In Stimulasi \& Aspek Perkembangan Anak (pp. 43-188). Kencana.

Susanto. (2017). Pendidikan Anak Usia Dini. PT Bumi Aksara.

Syaodih Sukmadinata, N. (2007). Metode Penelitian Pendidikan. Bandung: Remaja Rosda Karya.

Ulfah, M. (2019). Pendekatan Holistik Integratif Berbasis Penguatan Keluarga pada Pendidikan Anak Usia Dini Full Day. Jurnal Obsesi : Jurnal Pendidikan Anak Usia Dini, 4(1), 10. https://doi.org/10.31004/obsesi.v4i1.255

Yaswinda. (2019). Model Pembelajaran Sains Berbasis Multi Sensori Ekologi(PSB MUG) Bagi Anak Usia Dini. In Edu Publisher.

Yaswinda, Y., Yulsyofriend, Y., \& Mayar, F. (2018). Pengembangan Bahan Pembelajaran Sains Berbasis Multisensori Ekologi Bagi Guru Paud Kecamatan Tilatang Kamang Kabupaten Agam. Yaa Bunayya: Jurnal Pendidikan Anak Usia Dini, 2(2), 13-22. 